\title{
PRESCRIBING PATTERNS OF ANTIRETROVIRAL DRUGS IN A SECTION OF THE PRIVATE HEALTH CARE SECTOR OF SOUTH AFRICA
}

\section{Danie Scholtz}

M Pharm (Pharmacy Practice)

Academic intern, Pharmacy Practice, School of Pharmacy, North-West University (Potchefstroom Campus)

\section{Martie S Lubbe}

PhD (Pharmacy Practice)

Associate Professor: Head of Pharmacy Practice, School of Pharmacy, North-West University (Potchefstroom Campus)

Corresponding author: Martie.Lubbe@nwu.ac.za

\section{Jan HP Serfontein}

D Pharm (Pharmacy Practice)

Associate Professor: Head of Pharmaceutical Solutions and Research Group, Pharmacy Practice, School of Pharmacy, North-West University (Potchefstroom Campus)

\section{Dorcas Rakumakoe}

D Pharm

Senior lecturer, Pharmaceutic and Therapeutic Care, School of Pharmacy, North-West University (Potchefstroom Campus)

\section{Ronel Smit}

MBChB, DRCOG, ATLS, ACLS

Senior lecturer, Pharmaceutic and Therapeutic Care, School of Pharmacy, North-West University (Potchefstroom Campus)

Keywords: HIVIAIDS; antiretroviral drugs; South African private health sector; retrospective drug; utilisation; medicine cost

\section{List of abbreviations}

NRTIs: $\quad$ Nucleoside/Nucleotide Reverse Transcriptase Inhibitors

NNRTIs: $\quad$ Non-Nucleoside Reverse Transcriptase Inhibitors

Pls : $\quad$ Protease Inhibitors

Fls: $\quad$ Fusion Inhibitor

\section{ABSTRACT}

The general objective of this study was to investigate the prescribing patterns and cost of antiretroviral (ARV) drugs in the private health care sector in South Africa by using a medicine claims database. A quantitative, retrospective drug utilisation review was performed on data retrieved from 2001, 2002 and 2004 records. Antiretroviral drugs represented $0.38 \%$ ( $n=1475380$ ) for 2001, $0.72 \%$ ( $n=2076236)$ for 2002, and 1.68\% ( $n=2595254)$ for 2004 of all studied prescriptions. The total cost of the ARV drugs represented 1.31\% (R379 708 489) for 2001, 3.03\% (R601 350 325) for 2002, and increased to 5.25\% (R661 223 146) for 2004 of all drugs claimed. All ARV medicine items claimed during 2001 ( $n=9796)$ and 2002 ( $n=35271$ ) were innovator products. Only 5.23\% ( $n=5329)$ of all the ARV medicine items ( $n=101938$ ) claimed during 2004 were generic products. The average cost per ARV medicine item for 2004 increased from $R 317.93(S D=R 190.80)$ for the period January to April to $R 369.20(S D=R 219.50)$ for the 
period May to August, and decreased to R324.79 (SD = R212.48) for the period September to December and resulted in a cost saving of R41 044.35 for the period May to August versus September to December. Both the prevalence and cost of ARV drug therapy increased from 2001 to 2002. The prevalence increased from 2002 to 2004, but the cost decreased during 2004. The decrease in the cost of ARV drug therapy is probably a result of the implementation of the new pricing regulations in May 2004.

\section{OPSOMMING}

Die doel van hierdie studie was om die voorskryfpatrone en medisynekoste van antiretrovirale (ARV) geneesmiddels in die private gesondheidsorgsektor in Suid-Afrika te ondersoek. 'n Kwantitatiewe, retrospektiewe studie van medisyneverbruik vir die jare 2001, 2002 en 2004 is met behulp van 'n medisyne-eise databasis uitgevoer. Antiretrovirale geneesmiddels verteenwoordig vir 2001 0.38\% ( $n=1475$ 380), vir 2002 0.72\% ( $n=2076236$ ) en vir $20041.68 \%$ ( $n$ $=2595254$ ) van alle bestudeerde voorskrifte. ARV geneesmiddels verteenwoordig 1.31\% (R379 708489$)$ van die totale koste van medisyne geëis vir 2001, 3.03\% (R601 350 325) vir 2002 en toon 'n styging tot 5.25\% (R661 223 146) vir 2004. Alle ARV geneesmiddels wat gedurende $2001(n=9796)$ en $2002(n=35271)$ geëis is, was oorspronklike produkte. Slegs 5.23\% ( $n=5329)$ van die ARV geneesmiddels $(n=101938)$ wat gedurende 2004 geëis is, was generiese produkte. Die gemiddelde koste vir ARV medisyne-items het in 2004 soos volg toegeneem: $R 317.93$ (SA = R190.80) vir Januarie tot April, neem toe na R369.20 (SA = R219.50) vir Mei tot Augustus. ' $n$ Afname is gevind in die September- tot Desember-periode, naamlik R324.79 (SA = R212.48) wat ' $n$ kostebesparing van $R 41$ 044.35 veroorsaak het vir die tydperk Mei tot Augustus versus September tot Desember. Beide die voorkoms en koste van antiretrovirale geneesmiddelterapie het toegeneem van 2001 tot 2002. Die voorkoms het van 2002 tot 2004 toegeneem, maar die koste van geneesmiddelterapie het gedurende 2004 afgeneem. Die afname in koste kan moontlik die gevolg wees van die instelling van nuwe prysregulasies in Mei 2004.

\section{INTRODUCTION}

HIVIAIDS is already the leading cause of death worldwide (United Nations Children's Fund, 2004:10) with just over 5 million people out of a total of 46 million South Africans reported as HIV positive in 2004 , giving a total population prevalence rate of $11 \%$. This is estimated from the Actuarial Society of South Africa's demographic and AIDS model, which is based on a thorough analysis of a range of epidemiological and demographic data including the antenatal surveys up to the year 2002 (Dorrington, Bradshaw, Johnson \& Budlender, 2004:iii).

Many people infected do not have access to even the basic drugs needed to treat HIV-related infections and other conditions (Wikipedia, 2004). Projections indicate that, in the absence of antiretroviral treatment, the number of deaths due to AIDS is expected to result in a cumulative total of five to seven million in South Africa by 2010 (Dorrington, Bourne, Bradshaw, Laubscheer \& Timaeus, 2001). The relative high price of many of the antiretroviral (ARV) drugs and diagnostics on the other hand forms one of the main barriers to their availability in developing countries (United Nations Children's Fund, 2004:77). Weiser, Wolfe, Bangsberg, Thior, Gilbert, Makhema, Kebaabetswe, Dickenson, Mompati, Essex and Marlink (2003:281) found in a study in Botswana that the cost of ARV drug therapy was the most significant barrier to antiretroviral drug therapy adherence (44\%), followed by stigma (15\%), travel/migration (10\%) and side-effects (9\%).

Both the public and private sectors are implementing various interventions (Dorrington et al. 2004:2-3). These interventions are exercising a significant impact on the course of the epidemic. The mother-to-child transmission prevention programme has reduced the number of babies infected and behaviour change, in particular, has seen an increase in condom use and has reduced the number of adults infected. The national antiretroviral treatment programme can be expected to play a particularly important role in the future outcome of the epidemic (Dorrington et al. 2004:5). Bardi, Maartens, Mandalia, Bekker, Penrod, Platt, Wood and Beck (2006) finds antiretroviral therapy cost-effective in the 
treatment of people with AIDS in a South African setting. The cost of not using ARV drugs to treat people with AIDS was significantly greater.

\section{PRIVATE SECTOR INVOLVEMENT IN THE PROVISION OF ARV DRUGS}

Since January 2005, all medical schemes had to provide minimum benefits to members who had HIVIAIDS (Erasmus, 2005:1). Prescribed Minimum Benefits are benefits in respect of relevant health services prescribed by the Regulations under the Medical Schemes Act of 1998, Act 131 of 1998 (South Africa, 1998), as ammended in 2002. They were implemented in South Africa to prevent private sector patients who had to run out of medical cover in the event of serious illness from being denied health care services to the state hospitals without compensation from medical schemes, and also to encourage improved efficiency in the allocation of private and public health care resources. These regulations make provision for the medical and surgical management of opportunistic infections as well as localised malignancies as part of the prescribed minimum benefits. The Amendments of the General Regulations under the Medical Schemes Act of 1998, Act 131 of 1998, as ammended in 2004 had also added other services as part of the treatment of HIV infection (Erasmus, 2005:2) such as the following:

- $\quad$ HIV voluntary counselling and testing

- Co-trimoxazole as preventive therapy

- $\quad$ Screening and preventive therapy for tuberculosis (TB)

- Diagnosis and treatment of sexually transmitted infections

- $\quad$ Pain management in palliative care

- Treatment of opportunistic infections

- Prevention of mother-to-child transmission of HIV

- $\quad$ Post-exposure prophylaxis following sexual assault

- Medical management and medication, including the provision of ARV therapy, and ongoing monitoring for medicine effectiveness and safety, to the extent provided for in the national guidelines applicable in the public sector (Martinson, Radebe, Mntambo \& Violar, 2002:238; Stein, McLeod \& Achmat, 2002:60; Erasmus, 2005:2).
Over the last few years, most medical schemes have accepted responsibility for their members with HIV/ AIDS. In addition to legislated prescribed minimum benefits, most medical schemes contract the burden of HIV positive beneficiaries to disease management programmes, which were created to monitor the complex treatment and manage the significant costs associated with HIVIAIDS treatment (Connelly, 2002:8). Disease management programmes were introduced in order to provide a comprehensive management approach for beneficiaries of contracted medical schemes (Stein et al. 2002:10)

Disease management programmes potentially cover $89 \%$ of all health insurance beneficiaries. Even though beneficiaries of medical schemes have access to the disease management programmes, very few are registered into the programme. Only 18000 medical scheme members are registered with a disease management programme, representing less than $1 \%$ of all beneficiaries. This is low relative to the extent of the epidemic in South Africa as it is estimated that about $5 \%$ of al medical scheme members are HIV-positive (Martinson et al. 2002:239).

There were seven disease management programmes in operation in South Africa during 2002. These included the following: Accesshealth SA, Aid-for-AIDS, Calibre Clinical Consultants, Discovery Health, Lifesense, MX Health, Newmed and Qualsa (Stein et al. 2002:10).

The inclusion of antiretroviral therapy into the prescribed minimum benefits for HIV has a limited effect on medical schemes. This is the conclusion of a study done by Aid-for-AIDS, an innovative Medscheme initiative that looked critically at the number of beneficiaries registered on HIV-programmes in relation to the estimated HIV-prevalence within medical schemes (Medscheme, 2005:1). The study of Aid-for-AIDS was carried out on several medical schemes covering 680000 lives. An AIDS demographic modelling technique developed by the Actuarial Society of South Africa was used to estimate the HIV prevalence for these schemes. This was calculated to be $10 \%$ as of early 2005 . Based on data from the WHO, it was estimated that $21 \%$ of HIV positive patients should be on antiretroviral treatment. Using the $10 \%$ prevalence indicated by the modelling exercise, it equates to $2.1 \%$ of the 680000 lives. Currently, $1.9 \%$ of lives are actually on antiretroviral treat- 
ment, which is close to the estimated number who should be on treatment (Medscheme, 2005:1-2).

Because HIV is a relatively new infection, many of the drugs developed specifically to treat HIVIAIDS are still under patent protection in some countries and marketed at very high prices (Bellamy, 2001:6). Fourteen ARV drugs have been registered during the period 1989 to 2004 in South Africa (Medicine Control Council, 2004:1). These drugs include the Nucleoside/Nucleotide Reverse Transcriptase Inhibitors (NRTIs), Non-Nucleoside Reverse Transcriptase Inhibitors (NNRTIs) and Protease Inhibitors (PIs). Twenty ARV drugs were approved, as of October 2003, by the United States Food and Drug Administration (United States Food and Drug Administration, 2005:1), and these contain an extra drug class, namely the Fusion Inhibitor (Fls). De Clercq (2004:115) also described these four drug classes. Table 1 shows the number of ARV drugs registered with the Medicine Control Council for the period 1989-2004 (Medicine Control Council, 2004:1-4).

To date, information on the prescribing patterns and cost of ARV drugs in the private health care sector in South Africa is lacking. The following research questions can be formulated on the basis of the preceding discussion:

- What are the prescribing patterns of ARV drugs and what are the costs associated with these drugs in the private health care sector in South Africa?

- What is the prevalence and cost associated with the innovator and generic forms of ARV drugs in the private health care sector in South Africa?

It is thus imperative that research be conducted regarding the general prescribing patterns (prevalence and cost implications) associated with ARV drugs in the private health care sector of South Africa.

\section{DEFINITION OF TERMS}

Generic drug items: Generic drug items are pharmaceutical products usually intended to be interchangeable with the innovator drug items, manufactured without a licence from the innovator manufacturer and marketed after the expiry of patent or other exclusivity rights (World Health Organisation, 2003:116). Generic drug items contain the same active pharmaceutical ingredients, the same quantities thereof, and are in the same pharmaceutical dosage form as the innovator drug items.

Innovator drug items: Innovator drug items are the original patented pharmaceutical products. Innovator drug items are generally the products that were first authorised worldwide for marketing (normally as patented products) on the basis of the documentation of its efficacy, safety and quality, according to requirements at the time of authorisation. The innovator product always has a brand name; this may, however, vary among countries (World Health Organisation, 2003:116).

Drug item (medicine item): Drug item (medicine item) are defined according to the Medicines and Related substances Control Act of 1965, Act 101 of 1965 (South Africa, 1965) as "substance intended for use in the diagnosis, cure, mitigation, treatment, modification or prevention of disease, abnormal physical or mental state or the symptoms thereof in man". In this research the words "drug items" are used interchangeably with the words "medicine items". For the purpose of this study the term drug items exclude "dry goods", that is surgical equipment, non-medical drug items (needles, syringes) and mixtures (with unidentifiable active ingredients).

Weighted arithmetic mean: The weighted arithmetic mean is used when a joint arithmetic mean of different sets of data is computed from the arithmetic means of the individual sets.

\section{AIM OF THE STUDY}

The aim of this study was to investigate the prescribing patterns (prevalence and cost) of antiretroviral drugs in a section of the private health care sector of South Africa for 2001, 2002 and 2004.

\section{METHOD}

A retrospective drug utilisation study was done on antiretroviral drugs claimed through a national medicine claims database of a medical scheme administrator for the periods 1 January 2001 to 31 December 2001 , 1 January 2002 to 31 December 2002 and 1 January 2004 to 31 December 2004. Data of 2003 have been left out of the study due to the unavailability of the data for the whole 2003 and thus the usage and costs of drugs associated with this period cannot be compared 
with the other periods. During 2001, this medical scheme administrator, administered 50 medical scheme's data, during 2002, 51 medical schemes and during 2004, 80 medical scheme's data. Some of the medical schemes used formularies which could have an influence on the results.

This study focused specifically on prescriptions prescribed for patients who received ARV drugs. The quantity of ARV drugs (tablets, capsules) was a constant amount for 30 days. The prevalence and cost associated with ARV drug usage as well as the innovator and generic forms of ARV drugs were selected and utilised as measuring instruments for data analyses. All costs in the study are indicated in South African Rand (R). Antiretroviral drugs are divided into the

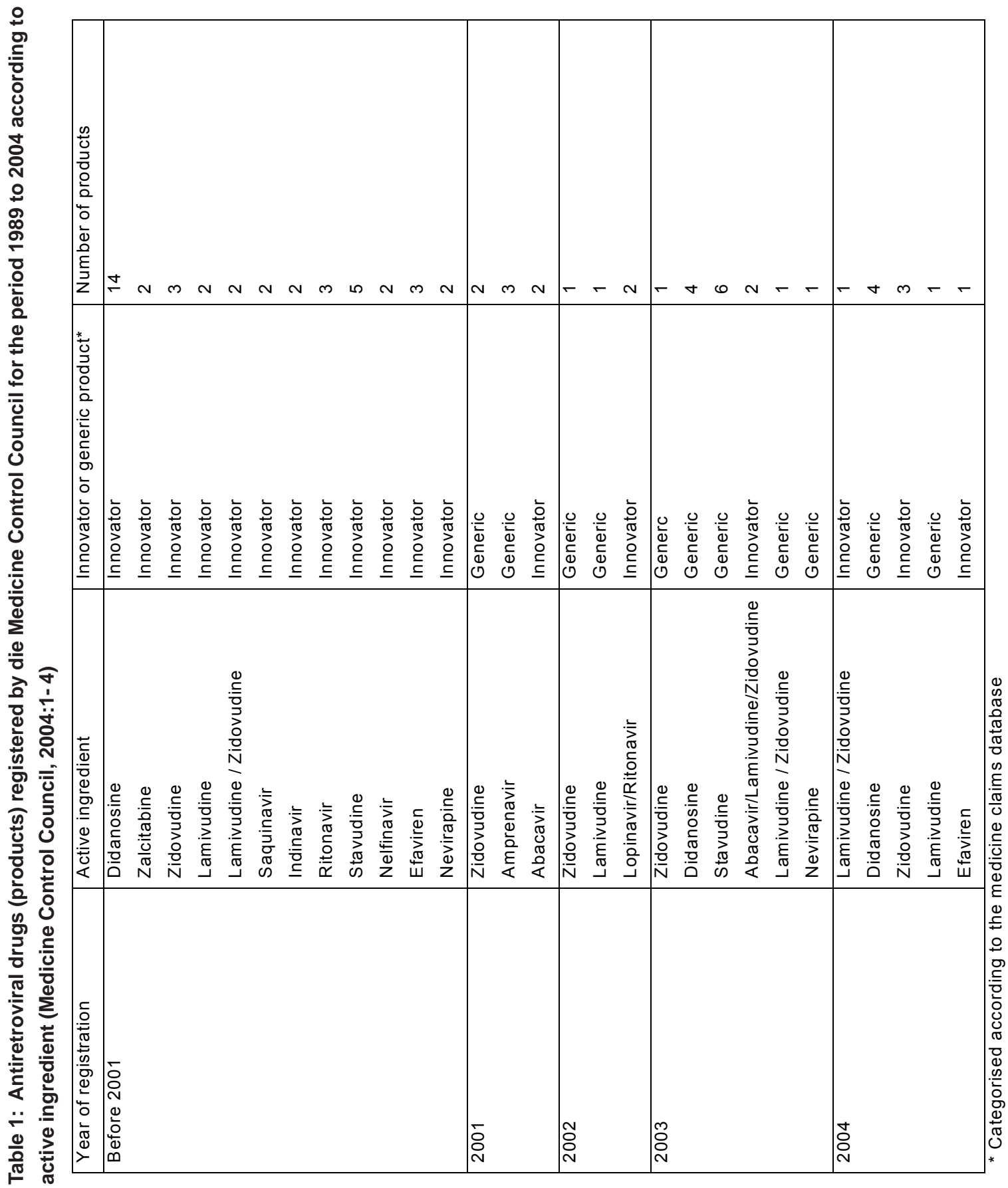


following categories (Medicine Control Council, 2004:1):

- Category I consists of Nucleoside/Nucleotide Reverse Transcriptase Inhibitors (NRTIs) items, namely abacavir, didanosine, lamivudine, stavudine, zalcitabine and zidovudine.

- Category II consists of Non-Nucleoside Reverse Transcriptase Inhibitors (NNRTIs) drug items, namely efavirenz and nevirapine.

- Category III consists of Protease Inhibitors (PIs) drug items, namely indinavir, lopinavir, nelfinavir, ritonavir and saquinavir.

- Category IV consists of OTHER ARV drug items, namely the combination of lamivudine/ zidovudine and the combination of lopinavir/ ritonavir.

To identify the possible influence of the introduction of the new pricing system during May 2004 on the prescribing patterns and cost of ARV, each year was divided in three time periods (four-month periods). In total there were nine four-month periods. The following time periods will be denoted in the discussion as follows: 1 January 2001 to 30 April $2001=$ P1; 1 May 2001 to 31 August $2001=$ P2; 1 September 2001 to 31 December $2001=$ P3; 1 January 2002 to 30 April 2002 = P4; 1 May 2002 to 31 August 2002= P5; 1 September 2002 to 31 December $2002=$ P6; 1 January 2004 to 30 April $2004=\mathrm{P} 7 ; 1$ May 2004 to 31 August $2004=$ P8; 1 September 2004 to 31 December 2004 = P9. P1, $\mathrm{P} 2$ and $\mathrm{P} 3$ are denoted the first study year, P4, P5 and $\mathrm{P} 6$ are denoted the second study year and P7, P8 and $\mathrm{P} 9$ are denoted the third study year.

Data were analysed by using the Statistical Analysis System $^{\circledR}$, SAS 9.1 (SAS for Windows, 9.1, 2005). Effect size (d-value) was used as a descriptive statistic (Steyn, 1999:3). The effect sizes were utilised in determining whether there were practical significant differences between averages. Ad-value of 0.8 or higher was assumed to have practical significance.

$$
d=\frac{x_{a-} x_{b}}{S 1}
$$

Where:

$\times a=$ the average medicine treatment cost of $a$.

$x b=$ the average medicine treatment cost of $b$.
$\mathrm{S} 1=$ the maximum standard deviation between $\mathrm{a}$ and b.

The weighted average was used when the joint arithmetic mean of different sets of data was computed from the arithmetic means of the individual sets (Steyn, Smit, Du Toit and Strasheim, 2003:102).

$$
\bar{y}_{w}=\frac{\sum w y}{\sum w}
$$

Where:

- $\bar{y}_{w}=$ weighted arithmetic mean

- $\sum w=$ sum of all given y values $\left(y_{1}, y_{2}, \ldots, y_{n}\right)$ with relative importance to all given $w$ values $\left(w_{1}, w_{2}, \ldots w_{n}\right)$

- $\sum w y=$ sum of all given $w$ values $\left(w_{1}, w_{2}, \ldots w_{n}\right)$

For the purpose of this study the cost-prevalence index was calculated as an indicator of the relative expensiveness of ARV drug items. Serfontein (1989:180) defined cost-prevalence index as follows:

$$
\text { Cost-prevalence index }=\frac{\text { Cost }(\%)}{\text { Prevalence }(\%)}
$$

The cost-prevalence index will be interpreted as follows:

- If cost-prevalence index $<1$ then the drug item utilised is relatively inexpensive.

- If cost-prevalence index $=1$ then there is an equilibrium between the cost and prevalence of the drug item.

- If cost-prevalence index $>1$ then the drug item utilised is relatively expensive.

Data were directly retrieved at the end of each year from the medicine claims database, thus no direct manipulation of the data by the researcher was possible. The datasets were verified by testing for outlying data, as well as by performing random data checks. For the purpose of this study surgical equipment, nonmedical items (needles, syringes) and mixtures (with unidentifiable active ingredients) were excluded from analysis.

Data for the analysis were obtained from one medicine 
claims database, thus, limiting external validity, implying that results can only be generalised to the specific database used, as well as to the specific study population. Each prescription record contained a unique number to identify each patient, medical practice, pharmacy or medical scheme. These numbers were randomly allocated by the medical scheme administrator providing the data to ensure confidentiality. Thus no specific patient, medical practice, pharmacy or medical scheme could be identified. Thus confidentiality of information was maintained throughout the study. The database consists of the following information:

- A specific code for the medical scheme (the specific medical scheme could not be identified)

- Medical scheme member number

- Dependent number

- Prescription number

- Date of dispensing the prescription

- A specific code for the medical practitioner (a specific medical practice could not be identified)

- A specific code for the pharmacy (a specific pharmacy could not be identified)

- Trade name of the drug item

- Nappi codes of the drug item

- Amount prescribed of a drug item

- The amount paid by the medical scheme

Limitations of the study were therefore that no gender, age, diagnoses or medical history (except for the drugs prescribed) were available. Permission to conduct the study was granted by the medical scheme administrator and the North-West University Research Committee.

\section{RESULTS}

\section{General prescribing patterns (prevalence and cost) of antiretroviral drugs}

Table 2 gives the general prescribing patterns of drug items as well as all ARV drug items for the three study periods, 1 January 2001 to 31 December 2001, 1 January 2002 to 31 December 2002 and 1 January 2004 to 31 December 2004. The percentage prescriptions claimed with at least one ARV drug item increased from $0.38 \%$ during 2001 , to $0.72 \%$ during 2002 , to $1.68 \%$ during 2004. The total number of patients who received one or more prescriptions for ARV drugs during 2001 was 1762 . This number increased to 4113 during 2002 and to 9065 during 2004. This increase may be the result of an increase in the total number of medical schemes and medical schemes members from 2001 to 2005 . The average number of ARV prescriptions per patient per year increased from $3.18(S D=2.51)$ in 2001 , to 3.65 (SD = 3.08) in 2002 to 4.78 (SD = 3.51) in 2004. The weighted average number of ARV drug items per prescription increased from $1.75(\mathrm{SD}=0.31)$ for 2001 , to 2.35 (SD = 0.03) for 2002 and remained stable on $2.35(\mathrm{SD}=0.02)$ for 2004

The results in Table 2 further reveal that the ARV drug items represented $0.33 \%$ of the total number of drug items claimed during 2001 . It further increased to $0.87 \%$ during 2002 and $1.92 \%$ during 2004 .

The total cost of ARV drug items constituted $1.31 \%$ of the total cost of all drug items claimed during 2001, $3.03 \%$ of the total cost of all drug items claimed during 2002 , and $5.25 \%$ of the total cost of all drug items claimed during 2004 (Table 2). The weighted average cost perARV prescription increased from R891.37 (SD $=\mathrm{R} 164.71)$ during 2001 to $\mathrm{R} 1215.35$ (SD = R155.29) during 2002 and then decreased to R798.37 (SD = $\mathrm{R} 45.60)$ during 2004. The same trend was also experienced with the weighted average cost per prescription of all other types of prescriptions on the database (Table 2).

The results in Table 2 show that the average cost per ARV drug item also increased from 2001, R509.48 (SD $=\mathrm{R} 155.66$ ) to $\mathrm{R} 517.00$ (SD = R64.18) during 2002 and decreased then to R340.55 (SD = R22.44) during 2004. According to the results in Table 3 , the average cost per ARV drug item for 2004 increased from R317.93 ( $S D=R 190.80)$ for the period January to April (P7) to R369.20 (SD = R219.50) for the period May to August (P8), and decreased to R324.79 (SD = R212.48) for the period September to December (P9). This resulted in a cost saving of R41 044.35 for the period May to August (P8) versus September to December (P9) for the ARV drug items.

\section{General prescribing patterns of innovator and generic antiretroviral drugs}

The results in Table 2 reveal that the total number of 


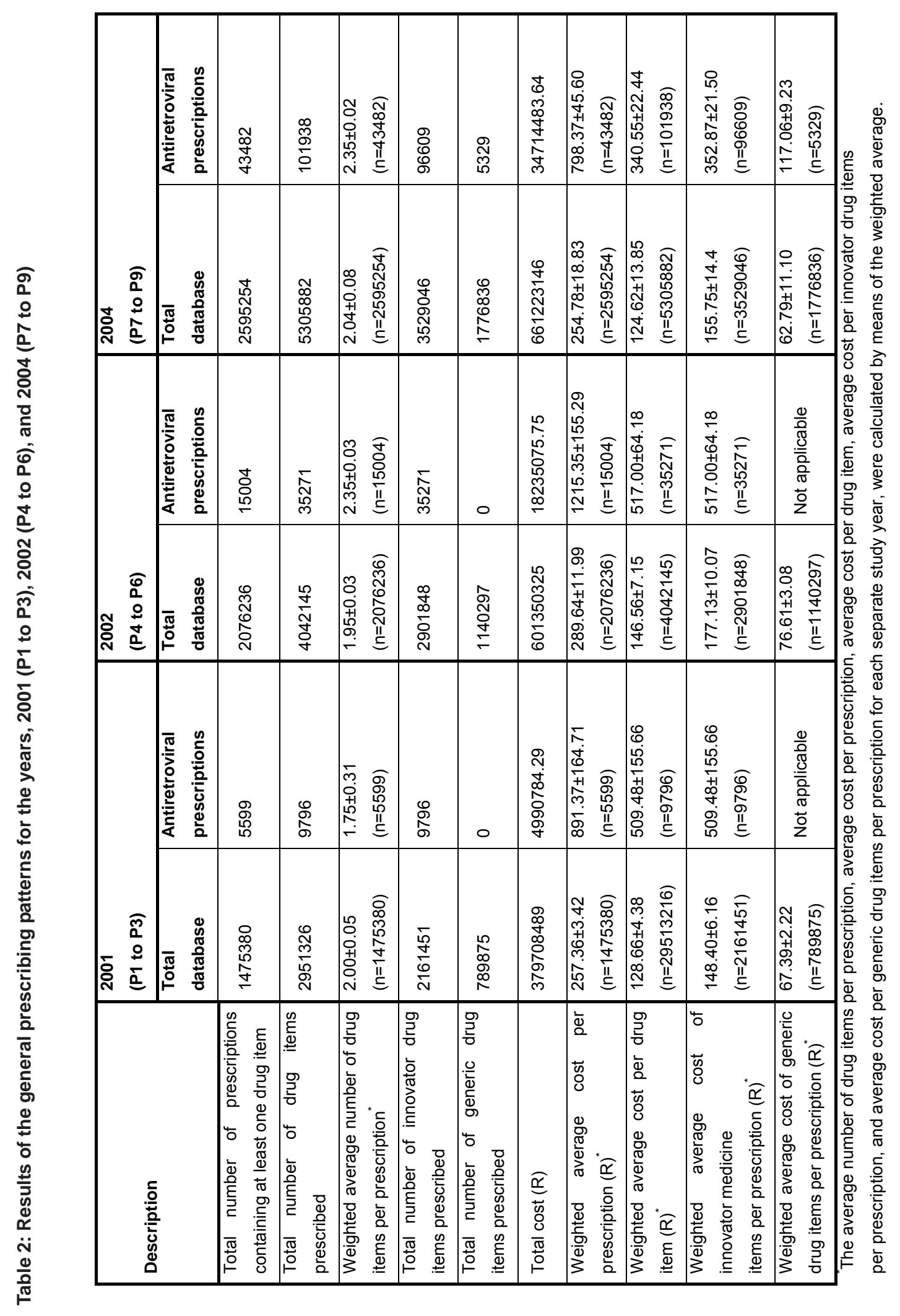




\begin{tabular}{|c|c|c|c|c|c|c|c|c|c|c|c|}
\hline \multirow{3}{*}{ 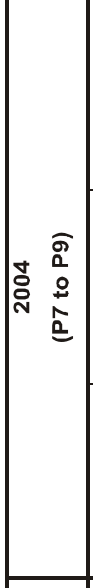 } & ஃ & $\begin{array}{l}\text { 苨 } \\
\text { d. }\end{array}$ & 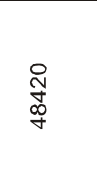 & $\begin{array}{l}\infty \\
0 \\
0 \\
01 \\
0 \\
i \\
i\end{array}$ & $\begin{array}{l}\bar{\delta} \\
\text { ơ }\end{array}$ & ్ָ & $\begin{array}{l}\hat{N} \\
0 \\
\hat{o} \\
o \\
N \\
\hat{N} \\
\stackrel{n}{n}\end{array}$ & 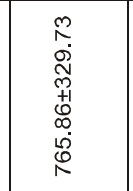 & 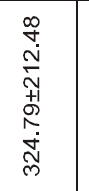 & 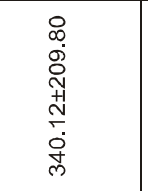 & 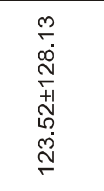 \\
\hline & $\stackrel{\infty}{\infty}$ & $\begin{array}{l}\infty \\
\stackrel{0}{0} \\
\stackrel{0}{\circ}\end{array}$ & $\begin{array}{l}\infty \\
\infty \\
\infty \\
\infty \\
\infty\end{array}$ & 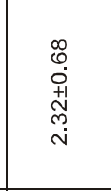 & $\begin{array}{l}\text { 常 } \\
\text { pen }\end{array}$ & $\underset{f}{\stackrel{f}{\square}}$ & 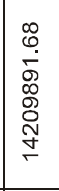 & 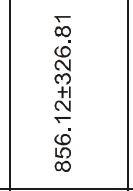 & 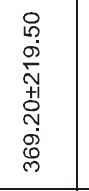 & 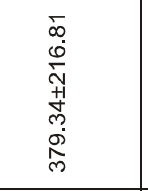 & $\begin{array}{l}0 \\
\infty \\
\infty \\
\infty \\
01 \\
0 \\
0 \\
\infty \\
\infty \\
0\end{array}$ \\
\hline & $\hat{a}$ & $\begin{array}{l}\text { 怘 } \\
\text { co }\end{array}$ & 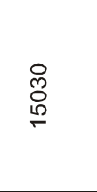 & $\begin{array}{l}N \\
\hat{N} \\
+1 \\
\hat{N} \\
i\end{array}$ & $\begin{array}{l}\stackrel{0}{0} \\
\stackrel{5}{+}\end{array}$ & $\stackrel{\square}{q}$ & 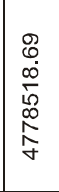 & 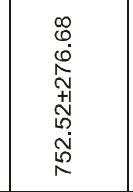 & 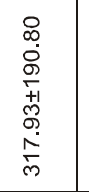 & 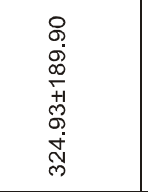 & 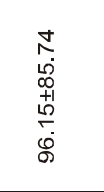 \\
\hline \multirow{3}{*}{ 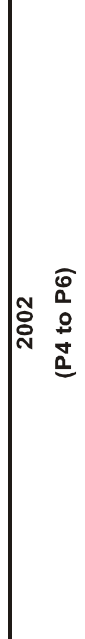 } & $\stackrel{0}{0}$ & 导 & $\begin{array}{l}\hat{\mathrm{v}} \\
\stackrel{\mathrm{v}}{\sim}\end{array}$ & $\begin{array}{l}0 \\
0 \\
0 \\
01 \\
0 \\
i \\
i\end{array}$ & $\begin{array}{l}\hat{\mathrm{V}} \\
\stackrel{i}{\sim}\end{array}$ & 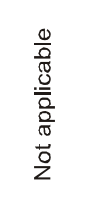 & $\begin{array}{l}0 \\
0 \\
0 \\
o+1 \\
\stackrel{N}{1} \\
\infty \\
\infty \\
\infty\end{array}$ & $\begin{array}{l}0 \\
0 \\
0 \\
0 \\
0+1 \\
+1 \\
0 \\
0 \\
0 \\
0\end{array}$ & 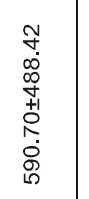 & 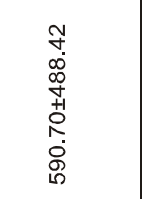 & $\begin{array}{l}\frac{0}{0} \\
\frac{0}{\overline{0}} \\
\frac{0}{0} \\
\frac{0}{2} \\
\frac{0}{2}\end{array}$ \\
\hline & ஜ & $\begin{array}{l}\stackrel{2}{9} \\
\stackrel{9}{g}\end{array}$ & $\stackrel{\Gamma}{\stackrel{\Gamma}{\infty}}$ & 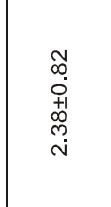 & $\stackrel{\Gamma}{\stackrel{\Gamma}{\infty}}$ & $\begin{array}{l}\frac{0}{0} \\
\frac{0}{00} \\
\frac{0}{2} \\
\frac{0}{\pi} \\
\frac{0}{2}\end{array}$ & 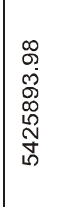 & 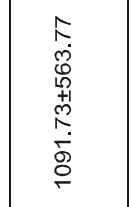 & 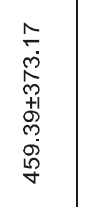 & 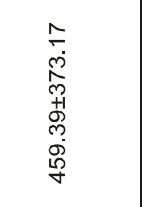 & $\begin{array}{l}\frac{0}{0} \\
\frac{0}{0} \\
\frac{0}{\overline{0}} \\
\frac{0}{0} \\
\frac{0}{2}\end{array}$ \\
\hline & I & $\begin{array}{l}\text { 足 } \\
\text { 怘 }\end{array}$ & $\stackrel{\mathscr{N}}{\stackrel{\infty}{\infty}}$ & $\begin{array}{l}\infty \\
\infty \\
0 \\
01 \\
0 \\
0 \\
i\end{array}$ & 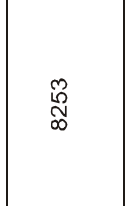 & $\begin{array}{l}\frac{0}{0} \\
\frac{0}{0} \\
\frac{0}{\overline{0}} \\
\frac{0}{0} \\
\overline{0} \\
\frac{0}{2}\end{array}$ & 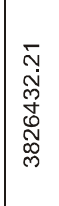 & 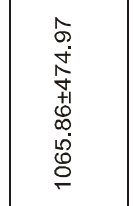 & 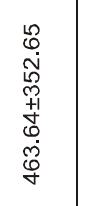 & $\begin{array}{l}\mathscr{0} \\
\stackrel{0}{0} \\
00 \\
0 \\
0 \\
0 \\
0 \\
\mathscr{\sigma}\end{array}$ & $\begin{array}{l}\frac{0}{0} \\
\frac{0}{\overline{0}} \\
\frac{0}{0} \\
\frac{0}{2}\end{array}$ \\
\hline \multirow{3}{*}{ 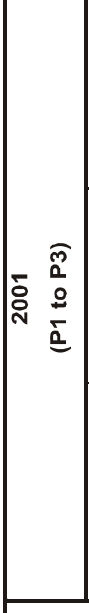 } & $\cong$ & 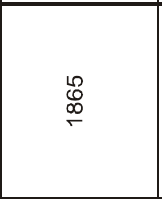 & 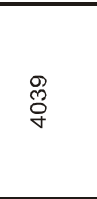 & $\begin{array}{l}0 \\
0 \\
0 \\
+1 \\
+1 \\
\end{array}$ & 令 & $\begin{array}{l}\frac{0}{\frac{0}{0}} \\
\frac{.00}{\overline{0}} \\
\frac{0}{\sigma} \\
\frac{0}{2} \\
\frac{0}{2}\end{array}$ & $\begin{array}{l}\circ \\
\stackrel{0}{1} \\
\hat{1} \\
0 \\
0 \\
0 \\
0 \\
\end{array}$ & $\begin{array}{l}\mp \\
0 \\
0 \\
o+1 \\
0 \\
0 \\
0 \\
\infty \\
\infty\end{array}$ & 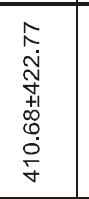 & \begin{tabular}{l}
$\hat{N}$ \\
\multirow{N}{*}{} \\
+ \\
+ \\
0 \\
0 \\
$\dot{\sigma}$ \\
$\dot{\sigma}$
\end{tabular} & $\begin{array}{l}\frac{0}{0} \\
\frac{0}{0} \\
\frac{0}{\overline{0}} \\
\frac{0}{0} \\
\frac{0}{2} \\
\frac{0}{2}\end{array}$ \\
\hline & $\tilde{\alpha}$ & $\underset{\mathbb{N}}{\mathbb{N}}$ & 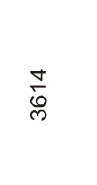 & 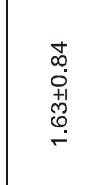 & 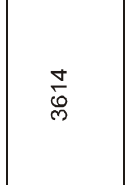 & $\begin{array}{l}\frac{0}{0} \\
\frac{0}{00} \\
\frac{0}{0} \\
\frac{0}{0} \\
\frac{0}{2} \\
\frac{0}{2}\end{array}$ & $\begin{array}{l}8 \\
0 \\
0 \\
0 \\
0 \\
0 \\
0 \\
10\end{array}$ & 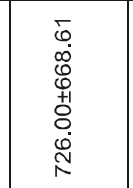 & $\begin{array}{l}\tilde{N} \\
\alpha \\
\infty \\
\infty \\
+1 \\
+1 \\
0 \\
0 \\
0 \\
j\end{array}$ & 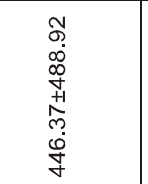 & $\begin{array}{l}\frac{0}{0} \\
\frac{0}{\overline{0}} \\
\frac{0}{0} \\
\frac{0}{0} \\
\frac{0}{2}\end{array}$ \\
\hline & $\bar{\Sigma}$ & $\stackrel{\text { N }}{\stackrel{5}{5}}$ & $\stackrel{\frac{q}{N}}{\text { d }}$ & \begin{tabular}{l}
$\infty$ \\
0 \\
0 \\
+1 \\
\multirow{1}{*}{} \\
$\check{c}$
\end{tabular} & $\stackrel{\text { q }}{\stackrel{N}{N}}$ & 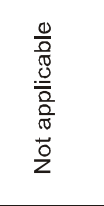 & 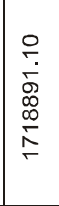 & $\begin{array}{l}\bar{n} \\
\stackrel{0}{0} \\
\stackrel{0}{+} \\
+1 \\
0 \\
0 \\
0 \\
\stackrel{0}{F}\end{array}$ & 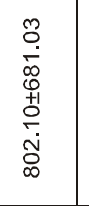 & 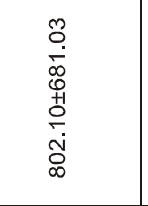 & $\begin{array}{l}\frac{0}{\frac{0}{\pi}} \\
\frac{0}{\overline{\overline{0}}} \\
\frac{0}{\pi} \\
\stackrel{0}{0} \\
z\end{array}$ \\
\hline 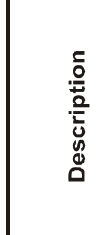 & & 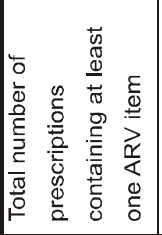 & 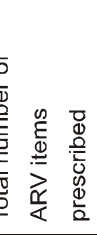 & 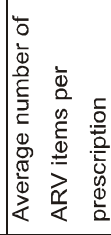 & 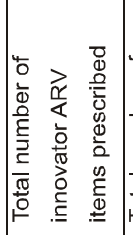 & 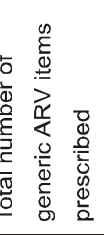 & 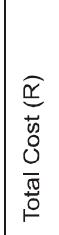 & 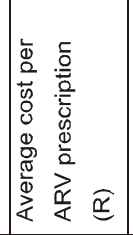 & 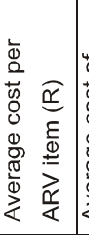 & 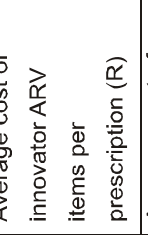 & 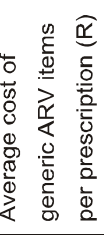 \\
\hline
\end{tabular}


innovator drug items claimed decreased from $73.24 \%$ during 2001 to $66.51 \%$ during 2004. All ARV drug items claimed during 2001 and 2002 were innovator products. Only $5.23 \%$ of ARV drug items claimed during 2004 were generic products.

The total cost of innovator ARV drug items decreased in 2001, and rose in 2002 and 2004, while the total cost of generic ARV drug items increased during 2004. The average cost per innovator ARV drug item decreased during 2001, increased during 2002, and during 2004 , it increased from R324.93 (SD = R189.00) in P7 to $R 379.34$ ( $S D=R 216.81)$ in $P 8$, and decreased to $\mathrm{R} 340.12$ (SD = R209.80) in P9. Thus, a decrease of $10.34 \%$ can be seen from P8 to P9. The average cost per generic ARV drug item steadily increased during 2004 (Table 3).

The effect sizes (d-values) calculated between the average cost per innovator ARV drug item and the average cost per generic ARV drug item for the entire study period are all greater than 0.8 , and of practical significance. The cost-prevalence index of the innovator ARV drug items was exactly one for 2001 and 2002, indicating that there was equilibrium between the cost and prevalence of these drug items utilised. The cost-prevalence index of the innovator ARV drug items was slightly higher than one for 2004, indicating that treatment was relatively expensive, while the cost-prevalence index of the generic ARV drug items for 2004 was lower than one, indicating that treatment with generic ARV drugs was relatively inexpensive (Table 3 ).

\section{Prevalence and cost of ARV drug items based on different categories}

Table 4 summarises the prevalence and cost of the different categories of ARV drug items, as described by the Medicine Control Council, the prevalence percentage and cost percentage as well as the costprevalence index calculated for the different periods, P1 to P3 (2001), P4 to P6 (2002), and P7 to P9 (2003).

The results in Table 4 indicate that category I represents the largest proportion of ARV drug items claimed during 2001, 2002 and 2004. Category III items is the group with the lowest prevalence for most of the four-month study periods of 2001, 2002 and 2004.
Categories I and IV of period P1 and category I of periods $\mathrm{P} 2$ and $\mathrm{P} 3$ respectively, have a cost-prevalence index of lower than one, indicating that it was relatively inexpensive. Remaining categories (II and III) of periods P1 to P3 of 2001 all have cost-prevalence indices of higher than one, indicating that these drug items were relatively expensive. Category I of periods P4 to P9 have a cost-prevalence indices of lower than one, indicating that they are relatively inexpensive. The remaining categories (II, III, and IV) of periods P4 to P9 all have cost-prevalence indices of higher than one, indicating that these categories are relatively expensive.

Category III ARV drug items of periods $\mathrm{P} 1$ and $\mathrm{P} 2$ have the highest weighted average cost per ARV drug item, being R2079.24 (SD = R456.23) and R655.65 (SD = $\mathrm{R} 132.93)$ respectively, while category IV of period $\mathrm{P} 3$ has the highest weighted average cost per ARV drug item, being R822.59 (SD = R831.99). Category IV of periods $\mathrm{P} 4, \mathrm{P} 5$ and $\mathrm{P} 6$ has the highest weighted average cost per ARV drug item, being R975.95 (SD = R465.99) for P4, R906.19 (SD = R512.28) for P5, and R1125.47 $(S D=R 36.17)$ for P6. The results of 2004 indicate that categories I, II, and IV of periods P7, P8, and P9 all have high prevalence and cost percentages.

\section{CONCLUSION}

The results of retrospective drug utilisation studies on a medicine claiming database provide a relatively inexpensive insight into the prescribing practices and cost of antiretroviral drugs in the private health care sector of South Africa. The aim of the study was to investigate the prescribing patterns (prevalence and cost) of antiretroviral drugs in a section of the private health care sector of South Africa by using a medicine claims database.

It was found that ARV drugs contributed to the prevalence and cost of all drug items available on the database. The percentage of prescriptions which contained one or more ARV drugs increased from $0.38 \%$ during 2001 to $1.68 \%$ during 2004. A similar trend was observed with the prevalence of ARV drug items, constituting a total prevalence of $0.33 \%$ for 2001 and $1.92 \%$ for 2004 . Although there was a relatively small increase in the average number of drug items per prescription per study year for the total database, the increase in the average number of ARV drug items per 
Table 4: Prevalence, cost and cost-prevalence index values of ARV drug items based on the different categories for the period P1 to P9

\begin{tabular}{|c|c|c|c|c|c|c|c|c|}
\hline Period & $\begin{array}{l}\text { Different } \\
\text { categories }\end{array}$ & $\begin{array}{l}\text { Number of } \\
\text { ARV items }\end{array}$ & $\begin{array}{l}\text { Prevalence } \\
\text { of ARV } \\
\text { items }\left(\%^{*}\right)\end{array}$ & $\begin{array}{l}\text { Cost of } \\
\text { ARV items } \\
(R)\end{array}$ & $\begin{array}{l}\text { Cost of } \\
\text { ARV items } \\
\left(\%{ }^{*}\right)\end{array}$ & $\begin{array}{l}\text { Cost- } \\
\text { Prevalence } \\
\text { index }\end{array}$ & $\begin{array}{l}\text { Average } \\
\text { cost } \\
(\mathrm{R})\end{array}$ & $\begin{array}{l}\text { Standard } \\
\text { deviation } \\
(\mathrm{R})\end{array}$ \\
\hline \multirow{4}{*}{$\mathrm{P} 1$} & Category I & 1434 & 66.92 & 1052142.37 & 61.21 & 0.92 & $733.71^{*}$ & 221.26 \\
\hline & Category II & 106 & 4.95 & 84079.54 & 4.89 & 1.00 & $793.20^{*}$ & 276.31 \\
\hline & Category III & 115 & 5.37 & 239112.48 & 13.91 & 2.59 & $2079.24^{*}$ & 456.23 \\
\hline & Category IV & 488 & 22.77 & 343556.71 & 19.99 & 0.88 & $704.01^{*}$ & 823.15 \\
\hline \multirow{4}{*}{ P2 } & Category I & 1998 & 55.29 & 644824.04 & 39.97 & 0.72 & $322.74^{*}$ & 155.11 \\
\hline & Category II & 533 & 14.75 & 295887.45 & 18.34 & 1.24 & $555.13^{*}$ & 18.14 \\
\hline & Category III & 133 & 3.68 & 87201.15 & 5.41 & 1.47 & $655.65^{*}$ & 132.93 \\
\hline & Category IV & 950 & 26.29 & 585263.45 & 36.28 & 1.38 & 616.07 & 804.30 \\
\hline \multirow{4}{*}{ P3 } & Category I & 2448 & 60.61 & 614653.55 & 37.06 & 0.61 & $251.08^{*}$ & 148.17 \\
\hline & Category II & 896 & 22.18 & 497651.59 & 30.00 & 1.35 & $555.42^{*}$ & 15.46 \\
\hline & Category III & 107 & 2.65 & 62730.95 & 3.78 & 1.43 & $589.56^{*}$ & 64.89 \\
\hline & Category IV & 588 & 14.56 & 483681.01 & 29.16 & 2.00 & $822.59^{*}$ & 831.99 \\
\hline $\begin{array}{l}2001 \\
\text { (P1-P3) }\end{array}$ & Total & 9796 & 100.00 & 4990784.29 & 100.00 & - & 509.48 & 155.66 \\
\hline \multirow{4}{*}{ P4 } & Category I & 4411 & 53.45 & 1264042.23 & 33.03 & 0.62 & $286.56^{*}$ & 163.25 \\
\hline & Category II & 2296 & 27.82 & 1197648.34 & 31.30 & 1.13 & $521.63^{*}$ & 14.20 \\
\hline & Category III & 279 & 3.38 & 128208.24 & 3.36 & 1.00 & $459.53^{*}$ & 126.82 \\
\hline & Category IV & 1267 & 15.35 & 1236533.40 & 32.32 & 2.11 & $975.95^{\star}$ & 465.99 \\
\hline \multirow{4}{*}{ P5 } & Category I & 6014 & 50.92 & 1594623.59 & 29.39 & 0.58 & $265.16^{*}$ & 181.54 \\
\hline & Category II & 3499 & 29.62 & 1897457.76 & 34.97 & 1.18 & $542.28^{*}$ & 27.28 \\
\hline & Category III & 445 & 3.77 & 254647.72 & 4.69 & 1.24 & $572.24^{*}$ & 469.40 \\
\hline & Category IV & 1853 & 15.69 & 1679164.91 & 30.95 & 1.97 & $906.19^{*}$ & 512.28 \\
\hline \multirow{4}{*}{ P6 } & Category I & 6385 & 41.99 & 1907190.23 & 21.23 & 0.51 & $298.70^{*}$ & 289.62 \\
\hline & Category II & 4607 & 30.30 & 2744212.90 & 30.55 & 1.01 & $595.66^{*}$ & 39.56 \\
\hline & Category III & 1107 & 7.28 & 833390.30 & 9.28 & 1.27 & $752.84^{*}$ & 716.40 \\
\hline & Category IV & 3108 & 20.44 & 3497956.13 & 38.94 & 1.91 & $1125.47^{*}$ & 36.17 \\
\hline $\begin{array}{l}2002 \\
(\mathrm{P} 4-\mathrm{P} 6)\end{array}$ & Total & 35271 & 100.00 & 18235075.75 & 100.00 & - & 517.00 & 64.18 \\
\hline \multirow{4}{*}{ P7 } & Category I & 5549 & 36.92 & 920247.43 & 19.26 & 0.52 & $165.84^{*}$ & 114.11 \\
\hline & Category II & 5218 & 34.72 & 2008329.30 & 42.03 & 1.21 & $384.89^{*}$ & 43.77 \\
\hline & Category III & 550 & 3.66 & 216943.12 & 4.54 & 1.24 & $394.44^{*}$ & 253.88 \\
\hline & Category IV & 3713 & 24.70 & 1632998.84 & 34.17 & 1.38 & $439.81^{*}$ & 24.99 \\
\hline \multirow{4}{*}{ P8 } & Category I & 13265 & 34.47 & 2383176.86 & 16.77 & 0.49 & $179.66^{*}$ & 157.10 \\
\hline & Category II & 13425 & 34.88 & 5997631.90 & 42.21 & 1.21 & $446.75^{\star}$ & 50.99 \\
\hline & Category III & 1831 & 4.76 & 926494.82 & 6.52 & 1.37 & $506.00^{*}$ & 361.61 \\
\hline & Category IV & 9967 & 25.90 & 4902588.10 & 34.50 & 1.33 & $491.87^{*}$ & 27.52 \\
\hline \multirow{4}{*}{ P9 } & Category I & 17982 & 37.14 & 2838646.99 & 18.05 & 0.49 & $157.86^{*}$ & 137.84 \\
\hline & Category II & 16901 & 34.91 & 6577607.91 & 41.83 & 1.22 & $389.19^{*}$ & 67.89 \\
\hline & Category III & 1901 & 3.93 & 945319.76 & 6.01 & 1.53 & $497.27^{*}$ & 377.69 \\
\hline & Category IV & 11636 & 24.03 & 5364498.61 & 34.11 & 1.42 & $461.03^{*}$ & 31.59 \\
\hline $\begin{array}{l}2004 \\
\text { (P7-P9) }\end{array}$ & Total & 101938 & 100.00 & 34714483.64 & 100.00 & - & 340.55 & 22.44 \\
\hline
\end{tabular}

\%* Prevalence/cost of the ARV items for a specific category divided by the prevalence/cost of the total number of ARV items for the same specific category, multiplied by hundred.

Weighted average 
prescription per study year was relatively higher with an increase of $34.29 \%$ for ARV drug items from 2001 to 2004. A study conducted on the lifetime cost of current human immunodeficiency virus care in the United States reported that from the time of entering HIV care, per person projected life expectancy is 24.2 years, discounted lifetime cost is US\$385 200, and undiscounted cost is US $\$ 618900$ for adults who initiate antiretroviral drug therapy with a CD4 cell count $<350$ / $\mathrm{mu}$ L. Seventy-three percent of the cost is antiretroviral medications, $13 \%$ inpatient care, $9 \%$ outpatient care, and $5 \%$ other HIV-related medications and laboratory costs (Schackman, Gebo, Walensky, Losina, Muccio, Sax, Weinstein, Seage, Moore \& Freedberg, 2006:990).

ARV drugs constituted $1.31 \%$ of the total cost of all drug items on the database for 2001 , increased to $3.03 \%$ during 2002 and increased to $5.25 \%$ for 2004 . Table 2 indicates an increasing trend in the weighted average cost per prescription for the period 2001 to 2002, and a decreasing trend for the period 2002 to 2004 . Possible reasons for the increasing trend for the period 2001 to 2002 could be the yearly cost inflation that resulted in higher manufacturing expenses and, in turn, higher drug prices. The results of a study conducted in two hospitals in Khon Kaen, Thailand during approximately the same time found that the average cost per outpatient visit with and without ARV drugs was US\$294.20 and US\$26.10, respectively (Kitajima, Kaboyashi, Chaipah, Sato, Chadbunchachai \& Thuennadee, 2003:2375).

The average cost per ARV prescription and the average cost per ARV drug item followed the same changing trends during the three study years with an increase from $P 7$ to $P 8$, and a decrease from P8 to P9. The effect sizes (d-values) calculated for the differences between the average cost per ARV prescription for the three study years have no practical significant value $(d<0.8)$, except for the effect size ( $d$-value) for the period $P 6$ to $P 7$, which has practical significant value $(d>0.8)$. The decreasing trend for the period 2004 could be due to the implementation of the new pricing regulations in May 2004 or the availability of more generic products on the market during 2004. On 30 April 2004, the Minister of Health published the medicine pricing regulations (Department of Health, 2004:3). From May to July 2004, pharmacists and dispensing doctors could still sell medicines as they had been doing in the past. On 2 August 2004 the practice of dispensing fees for pharmacists was officially being implemented and from 2 August 2004, dispensers could no longer charge a mark-up, and were entitled to charge the following dispensing fees (exclusive of VAT) for presciption medicine such as ARV drugs:

(a) twenty-six \% of the single exit price of a medicine where the single exit price of that medicine is less than one hundred rand;

(b) twenty-six rand in respect of a medicine where the single exit price of that medicine is greater than or equal to one hundred rand (Department of Health, 2004:14).

The prevalence percentages of ARV drug items increased during the three study years, while the cost percentages fluctuated during 2001 from $34.44 \%$ in P1 to $33.24 \%$ in P3, and increased during 2002 and 2004 . A cost-prevalence index of higher than one for periods $P 1, P 6$, and $P 8$ indicates that treatment was relatively expensive for these periods, while cost-prevalence indices of lower than one were calculated for the other periods, indicating that treatment was relatively inexpensive for those periods. The average cost per ARV drug item decreased by almost 50\% (R391.42) during 2001, and increased with $27.40 \%$ (R127.06) during 2002. During 2004 it increased with 16.13\% (R51.27) from P7 (before implementation of the new pricing system) to $\mathrm{P} 8$ (transition phase), and decreasing with $12.03 \%$ ( $n=R 44.41$ ) from P8 (transition phase) to P9 (after implementation of the new pricing regulations). Thus, the decreasing trend from P8 to P9 could be a possible effect of the implementation of the pricing regulations in May 2004.

It is evident from the results that there were no generic ARV drug items claimed during the first and second study years. An increase of $55.82 \%$ was found from 2002 to 2004 in generic products of the total medicine database, and an increase of $100 \%$ from 2002 to 2004 in generic ARV drug items on the database. The general increase in generic utilisation can be attributed to a combination of factors inter alia,

- managed care initiatives driving generic utilisation;

- the introduction of formularies that promote generic drugs utilisation for the management of various disease conditions, including the Prescribed Minimum Benefits;

- greater awareness of the availability and use 
of generic drugs by patients and health care providers; and

- mandatory generic subsitution at pharmacy level.

From the results it can be seen that the Protease Inhibitors (PIs) (category III) is the group representing the lowest prevalence and cost for most of the study periods. On the other hand, the Nucleoside/Nucleotide Reverse Transcriptase Inhibitors (NRTIs), (category I) represent the group with the highest prevalence for most of the study periods. Comparable results were found by Sabbatani (2003:473) in a study in Italy where the cost of antiretroviral drugs was determined within the period 1 January 2001 to 30 April 2002. In the 16 months under consideration $55.2 \%$ of the cost was associated with Nucleoside/Nucleotide Reverse Transcriptase Inhibitors (NRTIs), $25.97 \%$ with Protease Inhibitors (PIs) and $18.83 \%$ with Non-Nucleoside Reverse Transcriptase Inhibitors (NNRTIs).

The NRTIs (category I) and the OTHERARV drug items (category IV) of period P1 and the NRTIs (category I) of period $\mathrm{P} 2$ and $\mathrm{P} 3$ respectively, and the NRTIs (category I) of periods P4, P5 and P6, and the NRTIs (category I) of periods $\mathrm{P} 7, \mathrm{P} 8$ and $\mathrm{P} 9$ all have cost-prevalence indices of lower than one, indicating that their prevalence is slightly higher than the costs, and thus relatively inexpensive. The rest have a cost-prevalence index of higher than one, indicating that these drug items utilised are very expensive.

According to Wood, Braitstein, Montaner, Schechter, Tyndall, O'Shaughnessy and Hogg (2000:2095) limited health-care infrastructure and drug costs are the most important barriers to the widespread provision of ARV drug therapy in South Africa. The results of this study reveal that both the cost and prevalence of $A R V$ drug therapy have increased from 2001 to 2002, and the prevalence increased from 2002 to 2004 , but the cost decreased during 2004. The assumption can be made that an increase in prevalence could be due to an increase in the number of patients registering for HIV/ AIDS disease management programmes of medical schemes and that these patients are either more compliant or are using multiple therapies more frequently. The decrease in the cost of drug therapy is probably a result of the implementation of the new pricing regulations in May 2004 and an increase in the use of ge- neric ARV drugs. Wood et al. (2002:2095) found that the limited use of antiretroviral drugs could have an immediate and substantial impact on South Africa's AIDS epidemic

It is recommended that further drug utilisation studies on the prescribing patterns of antiretroviral drugs be conducted in South Africa, with specific focus on the influence of the new pricing system on the cost of ARV drugs in the private health care sector.

\section{ACKNOWLEDGEMENTS}

- The financial assistance of the National Research Foundation (NRF) towards the research is hereby acknowledged. Opinions expressed in this paper and conclusions arrived at, are those of the authors and are not necessarily to be attributed to the National Research Foundation.

- The medicine claims database that provided these data.

- Mrs Mèlanie Terblanche for assisting in proofreading the manuscript.

\section{REFERENCES}

BARDI, M; MAARTENS, G; MANDALIA, S; BEKKER, L; PENROD JR; PLATT, RW; WOOD, R \& BECK, EJ 2006: Cost-effectiveness of highly active antiretroviral therapy in South Africa. PLoS Medicine, 3(1):e4. Available from: www.plosmedicine.org [Accessed 12 July 2006]

BELLAMY, C 2001: Sources and prices of selected drugs and diagnostics for people living with HIVIAIDS. New York: UNICEF. CONNELLY, P 2002: The cost of treating HIVIAIDS with ARVs in South Africa: Who knows? Who cares? Available from www.iaen.org/files.cgi/6929_connely2.pdf [Accessed: 26 May 2005]

DE CLERCQ, E 2004: Antiviral drugs in current clinical use. Journal of Clinical Virology, 30:115-133.

DEPARTMENT OF HEALTH 2004: Medicines and Related Substances Act, 1965 (Act No. 101 of 1965). Regulations relating to a transparent pricing system for medicines and scheduled substances (Government notice No. R. 553, 2004). Government Gazette, 26304:3-24

DORRINGTON, RE; BOURNE, D; BRADSHAW, D; LAUBSCHEER, R \& TIMAEUS, I 2001: The impact of HIVIAIDS on adult mortality in South Africa. Cape Town: South African Medical Research Council.

DORRINGTON, RE; BRADSHAW, D; JOHNSON, L\& BUDLENDER, 
D 2004: The demographic impact of HIVIAIDS in South Africa. National indicators for 2004. Cape Town: Centre for Actuarial Research, South African Medical Research Council and Actuarial Society of South Africa.

ERASMUS, S 2005: HIV becomes prescribed minimum benefit. Available from: http://www.health24.com/medical/ Condition_centres/777-792-2002-2007,30583.asp [Accessed: 4 October 2005]

KITAJIMA, T; KABOYASHI, Y; CHAIPAH, W; SATO, H; CHADBUNCHACHAI, W \& THUENNADEE, R 2003: Cost of medical services for patients with HIVIAIDS in Khon Kaen, Thailand. AIDS, 17(16):2375-2381.

MARTINSON, N; RADEBE, B; MNTAMBO, M; \& VIOLAR, A 2002: Antiretrovirals. (In: Ijumba, P; Ntuli, A \& Barron, P eds. Health system review 2002. Durban: Health Sytems Trust. pp. 235-256.) MEDICINES CONTROL COUNCIL 2004: Antiretrovirals registered by the medicines control council for the period 1989-2004. Available from: http://www.mccza.com/documents/9.01\%20 Registration\%20of\%20antiretroviral\%20medicines\%208904.\%20Jul04v1doc.doc [Accessed: 28 June 2005]. MEDSCHEME 2005: Medical schemes cross HIVIAIDS hurdle. Website: http://www.health24.com/news/Medical_schemes/12035,30922.asp [Accessed: 23 May 2005].

SABATANIE, S 2003: A comparison of the therapeutic plan costs in the treatment of HIV-positive patients. Clinical Drug Investigation, 23(7):473-478

SCHACKMAN, BR; GEBO, KA; WALENSKY, RP; LOSINA, E; MUCCIO, T; SAX, PE; WEINSTEIN, MC; SEAGE, GR; MOORE, RD \& FREEDBERG, KA 2006: The lifetime cost of current human immunodeficiency virus in the United States. Medical Care, 44(11):990997.

SAS FOR WINDOWS 9.1 2005: SAS Institute Inc, 2002-2003. SERFONTEIN, JHP 1989: Medisyneverbruik in provinsiale hospitale met besondere verwysing na die rol van die apteker in die beheerproses. Potchefstroom: PU vir CHO. (Proefskrif-D.Pharm). SOUTHAFRICA 1965: Medicines and Related Substances Control Act, No. 101 of 1965. Pretoria: Government Printers.

SOUTH AFRICA 1998: Medical Schemes Act, No. 131 of 1998. Pretoria: Government Printers.

STEIN, A; McLEOD, H \& ACHMAT, Z 2002: The cover provided for HIVIAIDS benefits in medical schemes in 2002. CARE monograph Number 10. Cape Town: University of Cape Town, Centre for Actuarial Research.

STEYN, HS 1999: Praktiese beduidenheid: die gebruik van effekgroottes. Potchefstroom: $\mathrm{PU}$ vir $\mathrm{CHO}$.

STEYN, AGW; SMIT, CF; DU TOIT, SHC \& STRASHEIM, C 2003: Modern statistics in practice. Pretoria: Van Schaik.

UNITED NATIONS CHILDREN'S FUND 2004: The state of the world's children 2005. New York: UNICEF.
UNITED STATES FOOD AND DRUGADMINISTRATION 2005: Drugs used in the treatment of HIV infection. Available from: http:// www.fda.gov/oashi/AIDS/virals.html [Accessed: 28 June 2005]. WEISER, S; WOLFE, W; BANGSBERG, D; THIOR, I; GILBERT, P; MAKHEMA, J; KEBAABETSWE, P; DICKENSON, D; MOMPATI, K; ESSEX, M \& MARLINK, R 2003: Barriers to antiretroviral adherence for patients living with HIV infection and AIDS in Botswana. Journal of Acquired Immune Deficiency Syndromes, 34(3):281-288.

WIKIPEDIA 2004: AIDS. Available from: http://en.wikipedia.org/wiki/ AIDS [Accessed: 27 January 2005].

WOOD, E; BRAITSTEIN, P; MONTANER, JSG; SCHECHTER, MT; TYNDALL, MW; O'SHAUGHNESSY, MV \& HOGG, RS 2000: Extent to which low-level use of antiretroviral treatment could curb the AIDS epidemic in sub-Saharan Africa. Lancet, 355:2095-2100 WORLD HEALTH ORGANIZATION 2003: Medicine prices: A new approach to measurement. Geneva:World Health Organization. 